\title{
Socio-economic Impacts of Home Stay Accommodations in Malaysia: A Study on Home Stay Operators in Terengganu State
}

\author{
Md. Anowar Hossain Bhuiyan ${ }^{1}$, Chamhuri Siwar ${ }^{1} \&$ Shaharuddin Mohamad Ismail ${ }^{1}$ \\ ${ }^{1}$ Institute for Environment and Development (LESTARI), Universiti Kebangsaan Malaysia, Bangi, Malaysia \\ Correspondence: Md. Anowar Hossain Bhuiyan, Institute for Environment and Development (LESTARI), \\ Universiti Kebangsaan Malaysia, 43600 UKM, Bangi, Selangor Darul Ehsan, Malaysia. E-mail: \\ anowaranu@yahoo.com
}

Received: December 19, 2012 Accepted: February 6, 2013 Online Published: February 28, 2013

doi:10.5539/ass.v9n3p42

URL: http://dx.doi.org/10.5539/ass.v9n3p42

\begin{abstract}
Home stay accommodation gives focus on traditional life style, local culture and customs to attract the tourists. The present study examines the economic potentialities of home stay for operators. The study also analyzes socio-economic impact of this accommodation from the perception of operator's. Both primary and secondary data have been used in the study. A total of 10 home stay operators are selected from Terengganu for collecting primary data. The sample size has been determined based on non-probability convenience sampling design. Purposive sampling technique is used to select the respondents. Regression and descriptive analysis are using to attain the objectives. The study reveals that home stay is economically potential for the operators. Their monthly income rise based on initial investment, monthly expenses and targeted annual revenue. Moreover, the respondents believe this operation has helped local economy, society and environment. It gives focus on traditional culture and customs of local people. Home stay is increasing employment opportunities, local people living standard and public-private investment; and helpful for conservation and ecosystem to maintain the environmental balance. There are some initiatives such as proper planning and marketing, research activities, increase customer service and sufficient allocation can ensure socio-economic advancement from home stay accommodation.
\end{abstract}

Keywords: home stay, Malaysia, socio-economic, Terengganu

\section{Introduction}

Home stay is new accommodation arrangement in tourism industry. It is a potential and prospective accommodation system in tourism sector. This accommodation gives interaction opportunities to the tourists with local communities, cultural heritage, natural environment and social consistency. The government of country has facilitated home stay accommodations rather than large scale resort operation for early stage tourism development. This accommodation has limited capacity, facilities and service qualities for the customers. Home stay provides job opportunities for local communities and improves qualities of life for local people (Bhuiyan, Siwar, Ismail \& Islam, 2011a). Some necessary components for home stay are educational opportunities, entertainment facilities, food availabilities, proper arrangement of accommodation and hospitality (Levitt, 1986). The successful operation of home stay depends on active participation of local people. Home stay can ensure economic, social and cultural benefits for local communities as well as sustainable development (Chaiyatorn, Kaoses \& Thitphat, 2010). The participation of local people is influencing on social return from home stay accommodations. Home stay operators can contribute in various programs for improving the life standard of rural communities. Home stay program give focus on economic development and social enhancement of the operators (Bhuiyan et al, 2012). Different countries have different definition and concept for home stay accommodation. It is sued in Australia as farm stay, Japan and South Korea as educational home stay, South Africa as leisure stay, Canada as cultural and heritage home stay, USA as agriculture and educational home stay and Singapore as urban home stay (Hamzah, 2010). However, the general concept of home stay is same in all countries. Generally, home stay is different from other type's accommodations such as hotel, motel, lodging, camping. Home stay is helpful for enhancing tourism facilities in a country. It can solve accommodation problems for ecotourism, rural tourism and cultural tourism where tourists' are staying near the destinations. This accommodation is maintaining network between government and local people for tourism activities 
(Saeng-Ngam, Chantachon \& Ritthidet, 2009).

Tourism is one of the main earning sources for Malaysia. Tourism activities are contributing positively on country's economy by earning foreign exchanges and employment creation (Bhuiyan et al, 2011b). Malaysia has announced home stay as official tourism product in 1995. The Tourism Master Plan has recognized home stay as potential tourism product in 2001 (UNDP, 2003). The Malaysian home stay is differing from other countries definitions and concepts. Here guests are staying with operators family members and learn directly or indirectly from each other by exchanging culture, tradition and life style (Peterson, 2004). In Malaysia, home stay accommodation mainly operate and organized by the Kampung (village) people (Clammer, 1996; Kennedy, 1993). The home stay operators are developing Malay culture and activities in their accommodations. Necessary spaces, level of quality and security of houses are important elements for the home stay operation in Malaysia. Home stay program provides tourists multi ethnic life condition with cultural experiences and economic well beings for the local people (Liu, 2006). According to the Malaysian Home stay Association (MHA), foreign tourists from Japan, Australia, Korea and domestic tourists mainly students are the important client for home stay accommodations (Kayat, 2007).

Terengganu is one of the states of East Coast Economic Region (ECER) of Malaysia. There is some socio-economic backwardness situations are remaining in this state rather than other states of Malaysia. Among them poor incomes, unemployment, poverty, less urbanization, limited investment and poor infrastructure development are mentionable. But this state is full of natural and mineral resources, unspools beauties, islands, beaches, Islamic heritages and cultural attractions. Malaysian government give emphasize on tourism development in this state on the basis of these tourism attractions. Home stay may be a potential earning source for the local people in Terengganu. This accommodation gives focus on traditional life style, local culture and customs to attract the domestic and foreign tourists. This program can create commitment and genuine interest among the local people as well as local youth. The local people can ensure their socio-economic enhancement by participating in home stay program (ECER, 2007). The present study examines the economic potentialities of home stay accommodation for operators. The aim of the study is analyzing the socio-economic impact of home stay accommodations from the perception of operator's.

\section{Methods and Materials}

\subsection{Data Collection}

The study has used both primary and secondary data to attain the objectives. A total of 10 home stay operators are selected from three villages of Terengganu for collecting primary data. Among the respondents, three are selected from each village- Kampung Rhu 10 and Kampung Baru Penarik and four from Kampong Pasir Raja. Most of home stay accommodations in Terengganu are situated in these three villages. For this reason, the study has chosen these villages for primary data collection. A structured questionnaire has been used in this study with open and close ended items. The secondary data are collected from some reliable sources such as journals, books, government agencies, several reports.

\subsection{Overview of Sampling Villages}

Most of the families in Kampung Rhu 10 are living by fishing. The tourists are enjoying daily fishing life as well as the performance at night. Other mentionable activities of this village are fire-fly watching, dikir barat performance, handicrafts and batik canting. Kampung Baru Penarik is a fishing village situated near sea-beach. This village is famous for clean and beautiful sea-beach and sea-food restaurants. Kampong Pasir Raja is a traditional village and situated very close to Titiwangsa Mountain Range. The attractions of this village are traditional homes, natural beauty and Chemerong Waterfalls. The home stay accommodations of this village are attracting huge number of local and foreign tourists as well as child programs. Tourists are enjoying several activities here such as playing traditional games, rafting, making paddy oat flakes, cultural performances and opportunity to enjoy traditional dishes prepared by host families.

\subsection{Sampling and Data Analysis}

The sample size of this study has been determined based on non-probability convenience sampling design. This technique is based on calculated personal judgments and researchers utilize their own perceptions and knowledge to determine the sample size. The present study is a case study in nature. So, small sample (10) size has been determined to collect primary data due to time constraint and budget limitation. Purposive sampling technique is used to collect primary data from the respondents. The field survey has been conducted on third week of January, 2011. A regression model is used to analyze economic potentialities of home stay accommodation. Moreover, descriptive analysis is using to measure operators' perception on socio-economic 
impact of home stay. Statistical Package for Social Science (SPSS) software has been used in this study to analyze primary data.

\subsection{Home Stay in Malaysia}

The potentialities of home stay accommodations are increasing year by year in Malaysia. Home stay income rise $77 \%$ in 2009 from RM 6.4 million to RM 10.9 million compared to 2008. The tourists who stay in this accommodation are increased $77 \%$ in this period. Furthermore, total income of home stay entrepreneurs were RM 8.9 million and average occupancy rate of home stay were $22.7 \%$ within the period of January to October in 2010. Malaysia has targeted that home stay accommodation will contribute $5 \%$ of total earnings from tourism sector in 2020 (Ahmed, Abraham \& Zakaria, 2011).

Table 1 represents the total number of home stay participants in Malaysia. There were about 286 and 321 home stay program throughout the country in the year of 1997 and 1998 respectively. The numbers of home stay participants have risen then year after year. There were 1563 participants in 2006 and 3034 in 2008.

Table 1. Total number of home stay participants in Malaysia, 1997-2008

\begin{tabular}{lc}
\hline Year & Total Number of Home Stay \\
\hline 1997 & 286 \\
1998 & 321 \\
2002 & 776 \\
2004 & 948 \\
2006 & 1563 \\
2008 & 3034 \\
\hline
\end{tabular}

Source: Ministry of Tourism (2009)

\subsection{Home Stay in Terengganu}

Home stay accommodations is increasing year after year in Terengganu as like as Malaysia. Table 2 reveals the tourists arrivals to the home stay accommodation in Terengganu for the period of 2006-2008. The home stay accommodations attract 1,016, 1,338 and 446 domestic tourists in the year 2006, 2007 and 2008 respectively. On the other hand, a total of 119, 194 and 306 foreign tourists attracts by the year 2006, 2007 and 2008 respectively in Terengganu.

Table 2. Tourists arrivals to the home stay accommodation in Terengganu, 2006-2008

\begin{tabular}{cccc}
\hline Tourist Type & 2006 & 2007 & 2008 \\
\hline Domestic & 1,016 & 1,338 & 446 \\
Foreign & 119 & 194 & 306 \\
\hline
\end{tabular}

Source: Ministry of Tourism (2009)

Moreover, the numbers of villages and operators in home stay accommodations increase year by year in Terengganu. There are 5 and 7 villages facilitate home stay accommodations in Terengganu for the year 2006 and 2008 respectively. Furthermore, there were 82, 149 and 153 home stay operators in Terengganu for the year 2006, 2007 and 2008 respectively (Table 3 ). 
Table 3. Home stay accommodation according to village and operators in Terengganu, 2006-2008

\begin{tabular}{ccc}
\hline Year & Village & Operator \\
\hline 2006 & 5 & 82 \\
2007 & 5 & 149 \\
2008 & 7 & 153 \\
\hline
\end{tabular}

Source: Ministry of Tourism (2009)

\section{Results and Analysis}

Table 4 reveals the economic aspect of home stay accommodations on the basis of respondents' opinion. The minimum monthly families living expenses of the respondents are RM 1000 and maximum are RM 1800. Most of the respondents (70\%) have invested more than RM 51,000 for their home stay accommodations. The monthly incomes of the respondents from home stay are RM 600 to RM 2000. Most of the respondents' incomes are more than RM1000. The targeted maximum annual revenue of respondents is RM 96,000 and most of the respondents' annual targeted revenue is below RM 30,000. On the other hand, most of the respondents have reached in Break-even Period (BEP) within 2-3 years durations.

Table 4. Economic aspect of home stay accommodations

\begin{tabular}{|c|c|c|c|}
\hline Variable & Item & Frequency & $\begin{array}{c}\text { Maximum \& Minimum } \\
\text { Values }\end{array}$ \\
\hline \multirow{2}{*}{$\begin{array}{l}\text { Monthly Living Expenses } \\
\left(\mathrm{RM}^{*}\right)\end{array}$} & $1000-1500$ & 5 & Maximum 1800 \\
\hline & $1600-2000$ & 5 & Minimum 1000 \\
\hline \multirow[t]{2}{*}{ Initial Investment (RM) } & $<50,000$ & 3 & Maximum 90,000 \\
\hline & $>51,000$ & 7 & Minimum 30,000 \\
\hline \multirow[t]{3}{*}{ Monthly Income (RM) } & $<1000$ & 1 & Maximum 2,000 \\
\hline & $1100-1500$ & 5 & Minimum 600 \\
\hline & $1600-2000$ & 4 & \\
\hline \multirow{3}{*}{$\begin{array}{l}\text { Targeted Annual Revenue } \\
\text { (RM) }\end{array}$} & $<30,000$ & 5 & Maximum 96,000 \\
\hline & $31,000-50,000$ & 2 & Minimum 15,000 \\
\hline & $>51,000$ & 3 & \\
\hline \multirow{2}{*}{$\begin{array}{ll}\text { Expected } & \text { Break-even } \\
\text { Period (BEP) } & \end{array}$} & $2-3$ years & 9 & Maximum 4 years \\
\hline & $4-5$ years & 1 & Minimum 2 years \\
\hline
\end{tabular}

"RM- Malaysian Ringgit (\$1= RM3).

Here, we want to test,

$\mathrm{H}_{\mathrm{o}}: \beta=0$

$\mathrm{H}_{1}: \beta \neq 0$

The regression model is,

$$
Y=\beta+\beta_{1} X_{i 1}+\beta_{2} X_{i 2}+\beta_{3} X_{i 3}
$$

Where,

$\mathrm{Y}=$ Monthly Income

$\mathrm{X}_{\mathrm{i} 1}=$ Monthly living expenses

$\mathrm{X}_{\mathrm{i} 2}=$ Initial investment

$\mathrm{X}_{\mathrm{i} 3}=$ Targeted annual revenue 
Model Summary

\begin{tabular}{ccccc}
\hline 1 & $\mathrm{R}$ & $\mathrm{R}$ Square & Adjusted $\mathrm{R}^{2}$ & Std. Error of the Estimate \\
\hline 1 & .988 & .975 & .963 & 83.57176
\end{tabular}

Comments: Above model summary table shows that R-value is 0.988 that means the strong coefficient correlation are remaining between dependent and independent variables. $R$ square value 0.975 means that independent variables explaining the dependent variable 97.5 percent. The value of $R$ and $R$ square indicates that the model is good fit.

ANOVA

\begin{tabular}{cccccc}
\hline Model & Sum of Square & df & Mean Square & F & Sig. \\
\hline Regression & 1662094.564 & 3 & 554031.521 & 79.326 & .000 \\
Residual & 41905.436 & 6 & 6984.239 & & \\
Total & 1704000.000 & 9 & & & \\
\hline
\end{tabular}

Dependent Variable: Monthly income

From ANOVA table F statistic is (0.000) less than 0.10 (say level of significance 10\%). It also revealed that our model is about 99 percent true which means dependent variable is depend on independent variables.

\section{Coefficients}

\begin{tabular}{llccccc}
\hline \multirow{2}{*}{ Model } & & \multicolumn{2}{c}{ Unstandardized Coefficients } & Standardized Coefficients & & \\
\cline { 2 - 4 } & & $\mathrm{B}$ & Std. Error & Beta & $\mathrm{t}$ & Sig. \\
\hline \multirow{2}{*}{} & (Constant) & 753.692 & 182.127 & & 4.138 & .006 \\
& Monthly living expenses & -.518 & .118 & -.361 & -4.387 & .005 \\
& Initial investment & .019 & .002 & .837 & 10.917 & .000 \\
& Targeted Annual revenue & .008 & .001 & .483 & 6.630 & .001 \\
\hline
\end{tabular}

Dependent Variable: Monthly Income

From above coefficients table states that fitted regression model is,

$$
\mathrm{Y}=753.692+(-0.361) \mathrm{X}_{\mathrm{i} 1}+0.837 \quad \mathrm{X}_{\mathrm{i} 2}+0.483 \quad \mathrm{X}_{\mathrm{i} 3}
$$

In the above regression model, all coefficients are statistically significant at $1 \%$ level. From the above regression analysis we find out that all independent variables have a strong effect on our dependent variable monthly income. In the study revealed that monthly income rise of home stay holder's following the increase the amount of their initial investment and targeted annual revenue, those are positively related with dependent variable. But monthly living expenses has negative related with dependent variable while it increase then monthly income decreases that shown in minus sign.

Table 5 shows the perception of home stay owners towards socio-economic impacts of home stay operation. Most of respondents (80\%) agree that home stay is helpful to focus traditional culture where $10 \%$ disagree this. Maximum numbers of respondents $(80 \%)$ feel that home stay influences employment opportunities for local residents while $20 \%$ have no opinion. According to $80 \%$ of respondents, home stay is boosting social equity of local people and $20 \%$ disagree. $80 \%$ of respondents agree that home stay increases the quality of local people's life where $20 \%$ disagree this. The statement home stay is helpful for conservation is supported by $80 \%$ of respondents while $20 \%$ have no view. Most of respondents $(80 \%)$ support that public-private consultations are necessary for home stay development where $10 \%$ of respondents have no opinion and same portion disagree this. $90 \%$ of respondents agree that home stay increases the stability of local people life style where $10 \%$ not support this. In respect home stay is helpful for ecosystem, $90 \%$ of respondents agree this and $10 \%$ disagree. 
Table 5. Perception on socio-economic impacts of home stay

\begin{tabular}{|c|c|c|c|c|c|c|c|c|c|}
\hline \multirow[t]{2}{*}{ Statements } & \multicolumn{5}{|c|}{ Opinion Scale (\%) } & \multirow{2}{*}{$\begin{array}{l}\text { Mean } \\
\text { value }\end{array}$} & \multirow[t]{2}{*}{ S.D. } & \multirow{2}{*}{$\begin{array}{l}\text { Agreed } \\
(4 \& 5)\end{array}$} & \multirow{2}{*}{$\begin{array}{l}\text { Disagreed } \\
(1 \& 2)\end{array}$} \\
\hline & 1 & 2 & 3 & 4 & 5 & & & & \\
\hline \multirow{2}{*}{$\begin{array}{l}\text { Home Stay is helpful to focus } \\
\text { traditional culture }\end{array}$} & & 1 & 1 & 4 & 4 & 4.10 & .994 & 8 & 1 \\
\hline & & 10 & & 40 & 40 & & & $80 \%$ & $10 \%$ \\
\hline \multirow{2}{*}{$\begin{array}{l}\text { Home Stay influences employment } \\
\text { opportunities for local residents }\end{array}$} & & & 2 & 4 & 4 & 4.20 & .788 & 8 & \\
\hline & & & 20 & 40 & 40 & & & $80 \%$ & \\
\hline \multirow{2}{*}{$\begin{array}{l}\text { Home Stay is boosting social equity of } \\
\text { local people }\end{array}$} & & 2 & & 5 & 3 & 3.90 & 1.100 & 8 & 2 \\
\hline & & 20 & & 50 & 30 & & & $80 \%$ & $20 \%$ \\
\hline \multirow[t]{2}{*}{ Home Stay increases the quality of life } & & 2 & & 6 & 2 & 3.80 & 1.032 & 8 & 2 \\
\hline & & 10 & & 80 & 10 & & & $80 \%$ & $20 \%$ \\
\hline \multirow[t]{2}{*}{ Home Stay is helpful for conservation } & & & 2 & 4 & 4 & 4.20 & .788 & 8 & \\
\hline & & & 20 & 40 & 40 & & & $80 \%$ & \\
\hline \multirow{2}{*}{$\begin{array}{l}\text { Public-private consultations are } \\
\text { necessary for Home Stay Development }\end{array}$} & & 1 & 1 & 3 & 5 & 4.20 & 1.032 & 8 & 1 \\
\hline & & 10 & 10 & 30 & 50 & & & $80 \%$ & $10 \%$ \\
\hline \multirow{2}{*}{$\begin{array}{l}\text { Home Stay increases the stability of } \\
\text { local people life style }\end{array}$} & & 1 & & 3 & 6 & 4.40 & .966 & 9 & 1 \\
\hline & & 10 & & 30 & 60 & & & $90 \%$ & $10 \%$ \\
\hline \multirow[t]{2}{*}{ Home Stay is helpful for ecosystem } & & 1 & & 5 & 4 & 4.20 & .918 & 9 & 1 \\
\hline & & 10 & & 50 & 40 & & & $90 \%$ & $10 \%$ \\
\hline
\end{tabular}

\section{Discussion}

Home stay operation has potential socio-economic impact on the local communities. The owners have earned a major portion of their monthly expenses from the home stay accommodations. The initial investments of home stays are less than RM 100,000. But the owners have reached in the break-even point within 2-4 year period. That means the overall turnover from this accommodation is satisfactory level in terms of earning. This scenario creates a significant impact on employment creation and local economy. The regression analysis reveals that home stay operators get higher earnings by increasing their initial investment and annual revenues. Moreover, the earnings may be decrease if home stay operators' expand their monthly living expenses. The findings of this study show that home stay is economically profitable operation for the operators.

The description analysis of respondents' perception of the socio-economic impact of home stay accommodation shows that most of statements concerning this topic yielded a mean score in the high range. These statements are "Home Stay is helpful to focus traditional culture", "Home Stay influences employment opportunities for local residents", "Home Stay is helpful for conservation", "Public-private consultations are necessary for Home Stay Development", "Home Stay increases the stability of local people life style" and "Home Stay is helpful for ecosystem". This shows that the respondents believe home stay operation has helped the local economy, society and environment. This operation gives focus and highlights on traditional culture and customs of local people. It is keeping the stability of local people living standard and life style. In economic point of view, home stay is increasing employment opportunities and public-private investment. On the other hand, home stay is helpful for conservation and ecosystem to maintain the environmental balance. Again, two statements "Home Stay is boosting social equity of local people" and "Home Stay increases the quality of life" yielded a mean score in the minimum range. According to respondents, home stay operation is not highly effective for encouraging social equity and increasing the life quality of local people.

The potentialities of home stay accommodation to ensure socio-economic advancement of local people are as follows:

Economic involvement: Home stay accommodation increases income for existing local people in creating business opportunities. It makes active the labor market creates supplemental income from part-time jobs. It also increases revenue for local government.

Less environmental pollution: Water pollution is the most serious threat within environmental threats to 
sustainable tourism. Home stay creates less water pollution than big hotels. It also creates less solid waste and other garbage. Home stay accommodations are helpful to reduction in water and energy use.

Socio-cultural advantages: Due to differences in culture, some tourist behavior is perceived by residents in an area as culturally inappropriate. These behaviors create many socio-cultural problems in the area. In the home stay, tourists are stay in a local social environment. So, they may be respectful to preserve local traditions, stimulates cultural exchange, and encourages cooperation among local residents.

Employment opportunity: Home stay accommodation creates opportunity of employment for local communities. The local people may be engaged in various tourism related employment by home stay.

Investment opportunity: Home stay accommodation is a potential sector for investment in Malaysia. The entrepreneurs can return their investment from market with in short period.

Stable earning: Home stay accommodation ensure stable earnings for the operators. They can operate this program as an alternative and extra income sources with their main occupation.

\section{Conclusion}

Terengganu is ranked in backward position in terms of national economic development rather than other parts of Malaysia. The national GDP and investment rate also lower in the region. Home stay accommodation can be one of the major activities for economic development in this state. Local communities can benefit from this program as economically, socially and environmentally and culturally. Home stay accommodation increase the visitors' awareness of sustainability. It encourages the tourists to deliver culturally acceptable behavior towards locality. It also helps to reduce the environmental pollution as well as social degradation. So, local government can give emphasize home stay accommodation for the economic development of local people. Tourism policy should be formulated for enhancing home stay in the rural areas. Proper participation of home stay operators also ensure in this regard. Home stay is potential business operation for the local entrepreneurs. This accommodation will ensure employment opportunities and economic advancement for the local people. There are some initiatives such as proper planning and marketing, research activities, increase customer service and sufficient allocation can ensure socio-economic advancement from home stay accommodation.

\section{Acknowledgements}

Financial assistance provided from the Aras Perdana (AP) Research Grant, Institute for Environment and Development (LESTARI), Universiti Kebangsaan Malaysia (Ref. No. UKM-AP-PLW-04-2010) on 'Sustainable Regional Development of ECER, Malaysia' led by Emeritus Professor Chamhuri Siwar is gratefully acknowledged.

\section{References}

Ahmed, M. Z., Abraham, A. J., \& Zakaria, N. (2011). Home stay as a socio-economic community development agent: from UUM tourism management students' perspective. Proceedings of the Malaysian National Economic Conference (PERKEM VI), Malacca, Malaysia, June 5-7, 2011, Vol.2: 481-493. ISSN: 2231-962X

Bhuiyan, M. A. H., Siwar, C., Ismail, S. M., \& Islam, R. (2011a). The role of home stay for ecotourism development in east coast economic region. Am. J. of App. Sci., 8(6), 540-546. http://dx.doi.org/10.3844/ajassp.2011.540.546

Bhuiyan, M. A. H., Siwar, C., Ismail, S. M., \& Islam, R. (2011b). Potentials of Islamic tourism: A case study of Malaysia on east coast economic region. Aus. J. of Basic \& App. Sci., 5(6), 1333-1340.

Bhuiyan, M. A. H., Siwar, C., Ismail, S. M., \& Islam, R. (2012). Home stay accommodation for tourism development in east coast economic region. Am. J. of App. Sci., 9(7), 1085-1090.

Chaiyatorn, S., Kaoses, P., \& Thitphat, P. (2010). The developmental model of cultural tourism home stay of the Lao Vieng and Lao song ethnic groups in the central region of Thailand. J. Soc. Sci., 6, 130-132.

Clammer, J. (1996). Values and Development in Southeast Asia (1st ed.). Pelanduk Publications, University of Michigan, USA.

ECER. (2007). ECER Master Plan. Retrieved from http://www.ecerdc.com/ecerdc/dc.htm

Hamzah, A. (2010). Malaysian Homestays From the Perspective of Young Japanese Tourist: the Quest for Furusato. CIPD Monograph 2, Universiti Teknologi Malaysia (UTM), Johor, Malaysia.

Kayat, K. (2007). Customer orientation among rural home stay operators in Malaysia. ASEAN J. Hospitality 
Tourism, 6, 65-78.

Kennedy, J. (1993). History of Malaya (3rd ed.). S. Abdul Majeed and Co., Kuala Lumpur, Malaysia.

Levitt, T. (1986). The Marketing Imagination (1st ed.). Free Press, New York.

Liu, A. (2006). Tourism in rural areas: Kedah, Malaysia. Tourism Management, 27, 878-889. http://dx.doi.org/10.1016/j.tourman.2005.05.007

Ministry of Tourism. (2009). Tourism services division. Ministry of Tourism, Kuala Lumpur, Malaysia.

Peterson, M. (2004). Home stays in Malaysia. Transitions Abroad Mag., 28(3), 56-57.

Saeng-Ngam, A., Chantachon, S., \& Ritthidet, P. (2009). The organization of cultural tourism by the community people in the region of Toong Kula Rong Hai. J. Soc. Sci., 5, 342-347.

UNDP. (2003). Rural tourism master plan for Malaysia. Ministry of Tourism, Kuala Lumpur, Malaysia. 